\title{
Prosumption and the distribution and supply of electricity
}

\author{
Sandra Bellekom ${ }^{1}$, Maarten Arentsen ${ }^{1 *}$ and Kirsten van Gorkum²
}

\begin{abstract}
Background: Increasing numbers of households install renewable energy production systems like photovoltaic panels thereby contributing to a more sustainable energy system. Other developments, like in-home storage or peer-to-peer exchange within a neighbourhood, also contribute to the transition. This paper explores the emerging rise of these prosumers of electricity and its implications, in particular for grid management and electricity supply in the Netherlands.

Methods: With the help of an agent-based model, we illustrate the evolution of prosumption in a small Dutch-oriented residential community in five scenarios. The second part of the paper discusses the implications of the modelled rise in prosumption.

Results: Depending on the number of prosumers, combined with storage and peer-to-peer supply, we found a share of prosumption in this local community of about $28-30 \%$. The community will require less electricity from the central power plants. These model results also indicate that the management of the local network will become more important if more households become prosumers in combination with storage and peer-to-peer supply.

Conclusions: These trends affect current business models of DSOs and electricity production and supply companies. The latter are facing a loss of turnover which needs to be compensated by developing alternative business models. And, DSOs have to deal with the new needs on the local grid which also require an adaptation of their business models. Developing business models in cooperation with local energy communities could be an attractive alternative to explore.
\end{abstract}

Keywords: Prosumption, Residential storage, Peer-to-peer, Business models, Electricity supply companies, DSO, Electricity production companies

\section{Background}

The organisation and functioning of electricity supply have changed dramatically since the liberalisation agreements among the Member States and the European Union's (EU) enactment of the liberalisation directives in the 1990s. The electricity consumers experienced the changes in basically two different ways. First, consumers became able to freely choose an electricity supplier and to choose from a more diverse offering of products and services. For example, consumers can choose the most cost-effective supplier or choose a 'green' supplier that sells renewable energy, if desired locally produced. Second, consumers gradually moved into the position of themselves becoming an electricity producer as well as a consumer. The most prominent

\footnotetext{
* Correspondence: m.j.arentsen@utwente.nl

${ }^{1}$ CSTM University of Twente, Enschede, Netherlands

Full list of author information is available at the end of the article
}

example being households installing solar panels to (partly) produce their own sustainable energy. Both, choosing your electricity supplier and producing your own electricity, can contribute to the transition towards a more sustainable energy system. Prosumption, as it is called when consumers also become part of the production side of a product like electricity, was powerfully facilitated by a decline in the cost of photovoltaic (PV) technology [1], p9. According to the report of the International Energy Agency (IEA) [1], PV systems have initiated a prosumption trend enabling '... individual homes and businesses to invest in rooftop systems directly, based on economics but also on other possible motivations' [1], p5. The report continues: 'As a result of these trends, PV has been characterised as a "disruptive" technology which could revolutionise the utility sector just as personal computers and cell phones changed their respective industries' [1], p5. According to assessments by 
the International Energy Agency [1], about $25-35 \%$ of the global PV capacity is installed at the residential level. In the Netherlands the total amount of electricity generated by decentralised PV systems has increased tenfold between 2000 and 2014 [2]. It is predicted that power produced with residential PV systems will soon be or is already equally or less expensive than power produced centrally. According to some, this grid parity has already been reached for the Netherlands [3-6] but others think it might take another decade or more [7]. The growth of the number of PV systems in the Netherlands has been subject to variation due to changing subsidies [8]. However, we should not only focus on financial motives, also environmental reasons motivate households to choose renewable energy [9]. Other factors also influence the choice of households for PV panels, for example, the awareness and knowledge of the technology [10].

While the number of roof-top solar panels is increasing, the local exchange of electricity is still under development. Currently such an exchange is not supported in the Netherlands but (virtual) exchange is currently pilot tested in several projects, for example, in the well-known Powermatching City project [11].

Finally, also local storage is getting more attention recently. Two examples: 'Large scale lithium-ion batteries for energy storage are expected to become much more prevalent in 2012 as a result of technology advances and dropping prices' [12]. 'To date, the industry has focused a lot of attention on grid-scale storage, but it is the massive opportunity behind the metre that will truly move the industry from fledgling to mainstream' [13]. Sharma and Galipeau [14] studied the cost effectiveness of both load management and battery storage systems for individual households with PV systems. Castillo-Cagigal et al. [15] included load management (they call it active demand side management, ADSM) in their simulations and experiments with a combination of PV, storage and ADSM to maximise self-consumption. Based on data of seven Belgian households with PV panels, Mulder and his colleagues [16] calculated the optimal size of a hypothetical storage considering houses connected to the central grid. They did not strive for autonomy of the households but optimised the size of the battery to cover most of the electricity demand or to cover the peak power. Besides academically interesting, using battery systems to increase self-consumption of a household is also taken up by commercial parties. For example the German firm E3/DC recently introduced such a system [17-20]. All three developments could be part of local energy community. Several such communities are emerging in the Netherlands and abroad. They want to be more sustainable and/or become independent of large energy companies [21]. Residential photo-voltaic systems, storage facilities and peer-to-peer exchange can be part of a so called 'smart grid'. An example smart grid definition is provided by the European Energy Regulators [22]: 'A smart grid is an electricity network that can cost-efficiently integrate the behaviour and actions of all users connected to it - generators, consumers and those that do both - in order to ensure economically efficient, sustainable power systems with low losses and high levels of quality and security of supply and safety'. In general, the term smart grid is used to cover a large range of characteristics but all consider the electricity grid and the application of information technology see for example [23]. The development of smart grids is part of our transition to a more sustainable energy system [24]. Self-consumption can assist that transition. Although they support the energy transformation, liberalisation and the emergence of prosumers pose new challenges to the business model of the energy supply companies and the distribution system operators (DSOs). Distributed generation is becoming increasingly precarious for the electricity production companies due to their favoured position in the merit order in many countries and the need to retain conventional fossil-based capacity as a back-up. This undermines the dominant business case in electricity generation. Companies are forced to reconsider business models [25]. RWE, for example, responds with new models in 'innovation hubs' [26]. Gsodam et at [27] found that Austrian energy companies are still focussing on large-scale renewable production. They also acknowledge the importance of small-scale local production and the need for utilities to develop new business models to deal with that.

For the DSOs, increasing prosumption requires a refocus of their position and function in the electricity system. In all European countries, however, DSOs are regulated due to their function as the grid manager, in a monopoly position. Therefore, anticipating dynamics such as prosumption is not only a matter of business strategy, but also of politics and regulation. Initiatives and publications by international organisations and forums show that prosumption and its implications for electricity supply and grid management are currently hot topics in both research and discussion. The implications of prosumption are far from clear yet, as is the response of the DSOs and the energy companies.

\section{Related work}

Previous research studying the impact of prosumption merely focused on more technical and financial issues. Aspects that are studied are for example the grid tariff in systems similar to ours: local generation with PV systems and in-home storage [28]. Local generation reduces the amount of electricity obtained from the central grid and peak demand is not necessarily reduced because of local storage. Combined with a grid tariff that is largely based on the amount of electricity delivered centrally, this development does not reduce grid costs, but it does reduce the income of the grid company. This interesting 
article gives some possibilities for other grid tariff schemes. It differs from our approach in that we focus on a situation that includes peer-to-peer exchange and we further elaborate on business strategies for the energy companies involved. However, the model Jargstorf et al [28] presented could be useful to grid companies to study possible alternative grid tariff strategies. Our article on the other hand incentives them to study the impact of PV, inhome storage and peer-to-peer exchange on the demand of electricity itself.

A UK-based article by [29] compares local generation with PV and/or wind, at different locations. They do not include storage in their models; excess of locally generated power is directly fed back into the grid. Using this technology their model calculates a 47-73\% self-consumption. Pooling groups of consumers, like enabling peer-to-peer exchange, increases this number even further. Our model applies an extra technology, storage, but does not (yet) include different sources of local production which would be an interesting extension.

Other articles focus on residential or local storage systems. For example Wang et al. [30] focused on optimising the use of an in-home storage system combined with PV panels. Their goal was demand peak shaving which could reduce the household's electricity costs assuming a time of use energy tariff. Also Kahrobaee et al. [31] studied the optimal combination of local storage and production. Their work included wind turbines instead of PV panels. Others not only include the household's electricity bill but at the same time try to minimise investments required for the distribution grid [32].

\section{Emergence of prosumption and impact on distribution and supply companies}

The model we apply in this paper has three components: rooftop PV panels, peer-to-peer exchange of electricity and in-home storage. The model analyses the dynamic relation between these three components with the idea to see how it affects centralised grid based electricity production and consumption. This paper, therefore, adds to the debate on prosumption and its implications for grid management and energy supply by addressing and answering the following question: How could prosumption develop under liberalised market conditions and how would it affect the activities of DSOs and energy supply companies? The paper in particular addresses the impact of consumers producing, storing and supplying electricity peer-to-peer. We answer the central question in the following way. We first analyse the evolution of local electricity production and consumption with the help of an agent-based model (ABM), showing how prosumption at the local level might develop if the number of roof-top PV panels continues to rise, in combination with storage and peer-to-peer supply of electricity. Then, we reflect on possible implications of prosumption for grid management and electricity supply. The paper ends with some conclusions.

\section{Methods}

\section{Simulating evolution of prosumption in five scenarios}

This study considers a neighbourhood in which a number of households have rooftop solar panels and some of them also installed a storage system. Electricity produced by PV systems (the solar panels) cannot always be used real time by the household itself. This excess electricity can be delivered to the central grid, which is mainstream practice in the Netherlands at the moment. However, excess electricity could also be saved in a storage system, like a battery, and used at a later moment, for example during the night when the sun does not shine and the solar panels produce no electricity. With such storage systems, individual households become less dependent on the central grid.

We do not consider individual households or the distribution grid level but we focus on the community level. Besides residential PV and storage systems, our study also includes exchange of electricity within the neighbourhood. Electricity produced by the solar panels of one community member can be delivered to other members in demand for electricity.

To study how expansion in these three components, solar panels, residential storage and peer-to-peer exchange, influence the community's demand of the central grid we developed a model. With the help of the model, five future scenarios were simulated which differ in how the PV based electricity is used (Table 1).

The first scenario represents current electricity supply where households can have PV panels for self-consumption in combination with central grid exchange but without storage capacity and peer-to-peer exchange with community members. In this scenario, all surplus electricity is fed into the central grid.

In the second scenario, households combine PVbased electricity production with storage. Electricity surpluses produced by the PV panels feed into a battery to a maximum charge, and then to the grid. Electricity

Table 1 Five prosumption scenarios

\begin{tabular}{llll}
\hline & Residential storage & $\begin{array}{l}\text { Peer-to-peer } \\
\text { exchange }\end{array}$ & $\begin{array}{l}\text { Preferred application } \\
\text { of excess electricity }\end{array}$ \\
\hline Scenario 1 & No & No & - \\
Scenario 2 & Yes & No & - \\
Scenario 3 & No & Yes & - \\
Scenario 4 & Yes & Yes & Peer-to-peer exchange \\
Scenario 5 & Yes & Yes & Store \\
\hline
\end{tabular}


consumption is first satisfied by real-time PV production, then the battery, and lastly, the grid. Households are still operating individually; no community exchange is included in this scenario.

The third scenario allows peer-to-peer supply of electricity among community members, but now, storage is excluded. This scenario allows us to explore the implications of prosumption at the community level. Peer-to-peer supply here means that surplus electricity, produced by PV panels, is delivered to neighbours demanding electricity. All users prefer peer-to-peer supply over supply by the central grid.

Scenarios 4 and 5 combine storage and peer-to-peer supply, allowing studying the interaction between household and community level. We first simulate a scenario in which prosumers prefer peer-to-peer supply over storage. In this fourth scenario, prosumers have a community orientation.

In scenario 5, households prefer storage over peer-topeer supply, indicating a greater focus on individual independence from the grid compared to the community's independence.

We developed an agent based model (ABM) which calculates the community's electricity demand from the central grid or the community's self-consumpion (= reduction in demand from the grid). Within this ABM, individual households are 'agents'. Each household has its own characteristics like yearly electricity demand or capacity of their PV system. They follow simple rules in deciding how to fulfill their electricity demand. Electricity produced by PV systems is preferably used by the same household, excess production can be stored or shared with neighbours, depending on the scenario. From the behaviour of individual households emerges a behaviour of the community as a whole. This emergence is what we study. In the Netherlands, the number of residentially installed PV systems is growing rapidly [33]. Also internationally, PV systems show a strong progression [34].

Our agent-based model simulates the evolution of prosumption in a community by analysing the degree of selfconsumption under different conditions. The model assumes a varied number and capacity of PV and storage systems in the community. We define self-consumption by the community as electricity that is both produced and used within the neighbourhood, without interference from the central grid. The self-consumption of the community can be seen as a reduction in the neighbourhood's power demand from the central grid. Our model shows that prosumption combined with storage and peer-to-peer supply increases a community's off-grid electricity consumption.

More specifically, our model simulates a community of 300 private electricity consumers, representing a neighbourhood in a city or village. The community scale was inspired by the Dutch village of Waalre, with an active energy community and good prospects for prosumption by PV panels. Waalre is a wealthy municipality with large houses. Therefore, they can afford PV and storage systems and their houses are suitable for installing these systems. We took the average electricity consumption in Waalre of $4100 \mathrm{kWh}$ as our default value, which is slightly higher than the Dutch average. We basically focused on the aggregated daily self-consumption values. The model assumes different agents as, displayed in Fig. 1.

All agents are community members and users of electricity, but some combine consumption with production (prosumers), storage or supply of electricity. Agents can therefore play different roles: Consuming electricity provided by the grid or by community peers (consumers with access to electricity) or consuming electricity by own production and storage. The model simulates the 24-h cycle of electricity production and consumption within the community. The Appendix provides detailed information on the model's features, default values, assumptions and model runs.

After the presentation of the scenarios we discuss the implications of presumption for DSOs. This part of the analysis is based on observations in the market, literature and media coverage, with The Netherlands as focal point. So, here, the article basically reflects what is or might happen in the Netherlands if prosumption develops as simulated by the scenarios.

\section{Results}

Five scenarios of community prosumption development This section presents and discusses the five scenarios based on model runs. We present the results in similar graphs with the vertical axis representing the community's selfconsumption expressed as a percentage of the community's

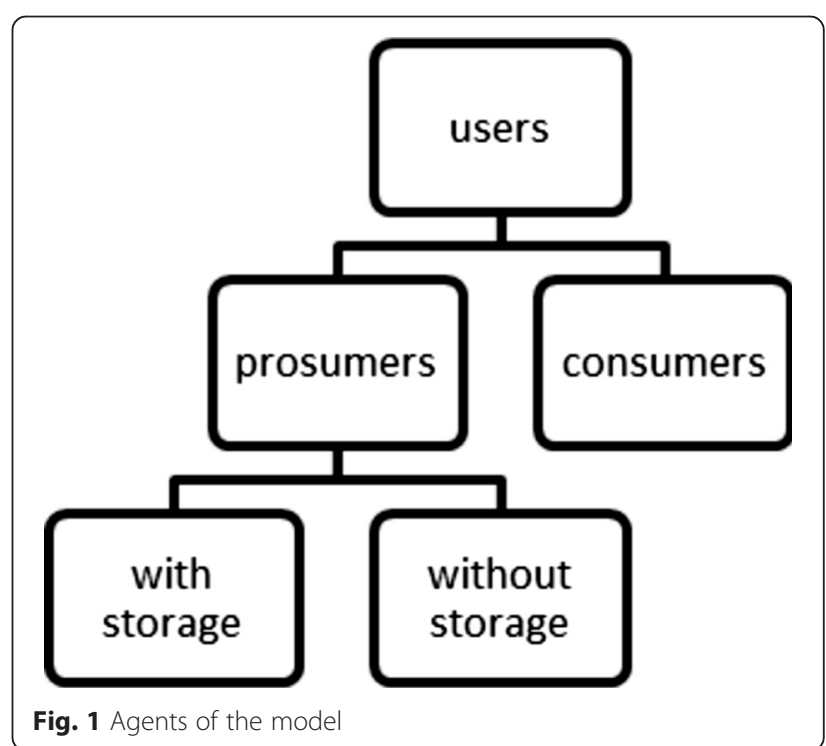


total electricity consumption. Total self-consumption includes consumption from installed photovoltaic systems, residential storage systems, and peer-to-peer supply and equals the reduction in the community's electricity demand from the central grid. On the horizontal axes of the graphs the studied parameters are varied. Table 2 lists the default values of these parameters and the range of values we simulated. In the Appendix an explanation for the applied default values is given (Fig. 2).

The number of community members and the average capacity of storage systems turned out to be factors that hardly influence the self-consumption. Therefore, no graphs of these variables are included. Although both summer and winter conditions were simulated we focus in our results on the self-consumption during summer months.

\section{Share of users with a PV system}

While changing the share of community members with rooftop PV systems, the other parameters were kept at default values. An increasing number of PV systems increases the community's self-consumption linearly in the first 2 scenario's where no peer-to-peer exchange is allowed. In these scenario's the community's self-consumption is just a summation of the individual self-consumptions of the community members. The linear increase indicates that the electricity produced by the PV systems is consumed by the households in real time or stored in the household's battery. Scenario 1 shows a slightly lower selfconsumption compared to scenario 2, indicating the increased self-consumption when storage facilities are applied. In the other scenarios, the increase in the number of PV panels in the community increases the community's self-consumption, but the effect is

Table 2 Modelled parameters with default value and simulated range

\begin{tabular}{lll}
\hline Parameter & Default value & Simulated range \\
\hline $\begin{array}{l}\text { Average yearly demand } \\
\text { Number of users/ } \\
\text { community members }\end{array}$ & $4100 \mathrm{kWh}$ & - \\
$\begin{array}{l}\text { Share of users with } \\
\text { PV system }\end{array}$ & 300 & $0-500$ \\
$\begin{array}{l}\text { Average capacity of } \\
\text { PV system }\end{array}$ & $3000 \mathrm{Wp}(=3 \mathrm{kWp})$ & $0-100 \%$ \\
$\begin{array}{l}\text { Share of PV systems } \\
\text { with storage system }\end{array}$ & $25 \%$ & $0-100 \%$ \\
$\begin{array}{l}\text { Average capacity of } \\
\text { storage system }\end{array}$ & $4 \mathrm{kWh}$ & $0-20 \mathrm{kWh}$ \\
$\begin{array}{l}\text { Storage level at start } \\
\text { (= amount of energy } \\
\text { in the battery at the } \\
\text { beginning of the } \\
\text { simulation) }\end{array}$ & $0 \%$ of capacity & $0-100 \%$ \\
\hline
\end{tabular}

levelled off at higher PV system penetration. When almost all households in the community have installed PV systems, exchanging energy within community is no longer possible, since households produce enough for themselves. Scenario 3 results in a lower self-consumption than scenarios 4 and 5 since no storage of excess electricity is possible. The figure also shows that in scenario 2 the levelling off is more pronounced, which is a result of the lack of storage.

\section{Average capacity of PV system}

While studying the influence of the average capacity of the residential photovoltaic installations other parameters, like the share of households with installed PV systems, are kept at default value. The total number of PV systems in the default model thus equals 60 (20\% of 300 ). The graph of scenario 1 in Fig. 3 shows only a small increase in community's self-consumption at increasing PV panel capacity. In this scenario, the surplus electricity produced by the panels is directly fed into the central grid, none is stored or shared with the neighbours. The effect of introducing a few storage systems in the community is seen when comparing scenario 1 and 2 . The possibility to store excess electricity produced by the PV systems slightly increases the self-consumption. In both scenarios, a levelling off is visible for high capacities, indicating that such PV systems produce more energy than can be used by a single household. Allowing for peer-to-peer exchange in the community has a much stronger effect; the community's self-consumption in scenarios 3,4 and 5 is considerably higher than in scenarios 1 and 2. Adding storage to a community with peer-to-peer exchange hardly increases the community's self-consumption.

Comparing Figs. 1 and 2 reveals that increasing the number of solar panels in a neighbourhood increases the selfconsumption more severely than increasing the capacity of these panels to $20 \%$ (default value for share of users with PV systems) of roofs.

\section{Share of PV systems with storage system}

Since in scenarios 1 and 3 no storage is included, Fig. 4 only shows graphs for scenarios 2,4 and 5 , the difference between scenario 2 and scenarios 4 and 5 being peer-to-peer exchange of electricity. Without such exchange (scenario 2 ), households behave individually. Increasing the share of batteries from zero (0\% of 60 households with PV panels) to 60 (100\% of 60 households with PV panels), results in an almost linear growth of the community's selfconsumption. The default battery capacity of $4 \mathrm{kWh}$ seems to be sufficient to store all excess electricity for use later on the day. Including peer-to-peer exchange (scenarios 4 and 5) results in a higher self-consumption of the community. However, this is hardly related to the number of storage 


\section{Summer}

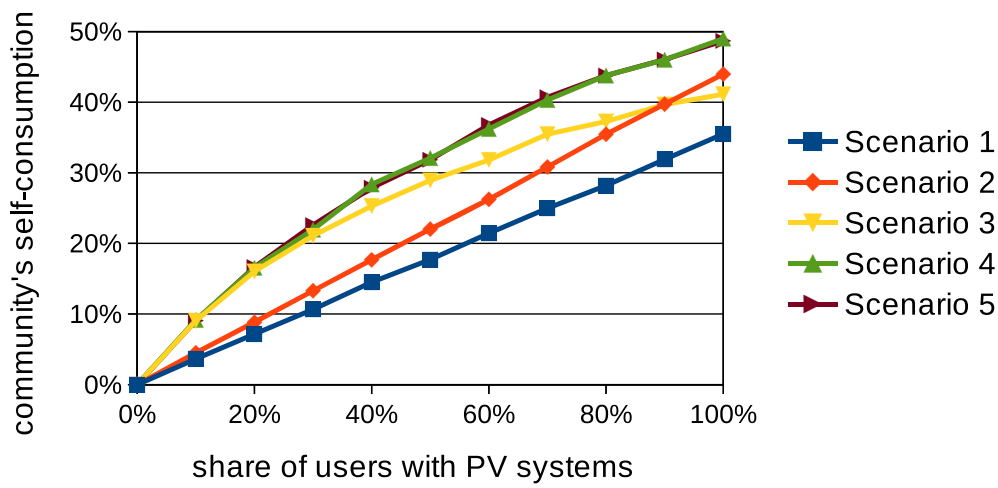

Fig. 2 Simulation results for a summer day modelling the share of community members having installed a photovoltaic system

systems. Adding peer-to-peer exchange seems more effective in increasing the self-consumption than adding (more) batteries. This might be related to the relatively small number of storage systems we simulated in our model.

\section{Storage level at start}

(= amount of energy in the battery at the beginning of the simulation).

While in the previous simulations, we assumed an empty battery to start with, we now introduce batteries that already contain some energy at the beginning of the simulation. However, keep in mind the rather small number of default storage systems in the model, 15 ( $25 \%$ of 60 PV systems). There is hardly any influence from the stored energy in the battery on the selfconsumption of the community, as can be seen in Fig. 5 . Perhaps a small increase in self-consumption is visible but since we simulate only one day this might be due to emptying the battery during the day. Since battery power is not used for peer-to-peer exchange, the (very slight) slopes of scenario 2 and of scenarios 4 and 5 are the same.

\section{Comparison of the five scenarios}

Table 3 shows the community's self-consumption as a percentage of the total consumption. To highlight the amount of electricity the community can produce and consume without interaction with the central grid, the listed results correspond to a summer's day. Each row gives the self-consumption in one of the five simulated scenarios. The first column shows the range of selfconsumption values obtained from the model runs, while the default values are applied for the number of PV systems $(20 \%$ of users $=60)$, average PV capacity (3 $\mathrm{kWp}$ ), number of community members (300), number of storage systems $(25 \%$ of PV systems $=15)$, average storage capacity $(4 \mathrm{kWh})$, and level of energy in the battery at the start ( $0 \%$ of storage capacity). In the next columns each of these parameters is doubled, one at a time. Since doubling $0 \mathrm{kWh}$ in the storage system at the start

\section{Summer}

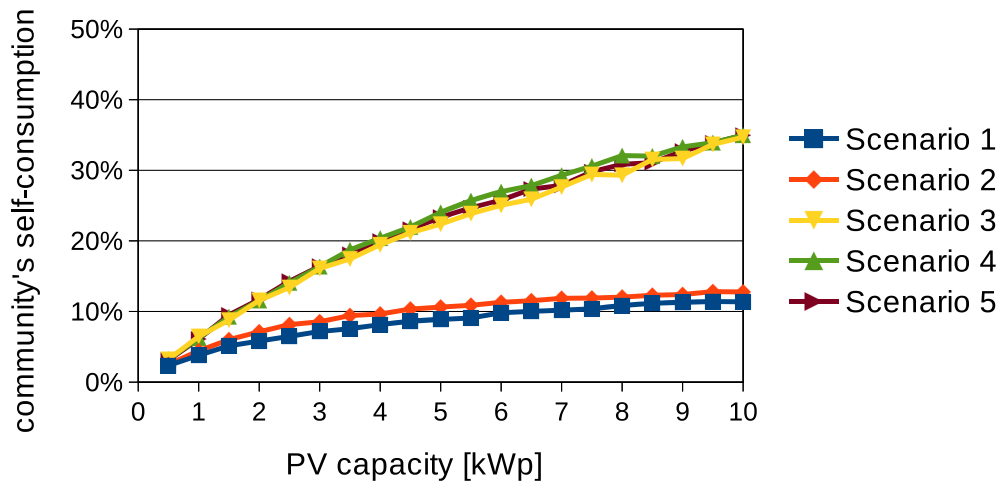

Fig. 3 Simulation results for a summer day modelling the average capacity of the installed photovoltaic systems 


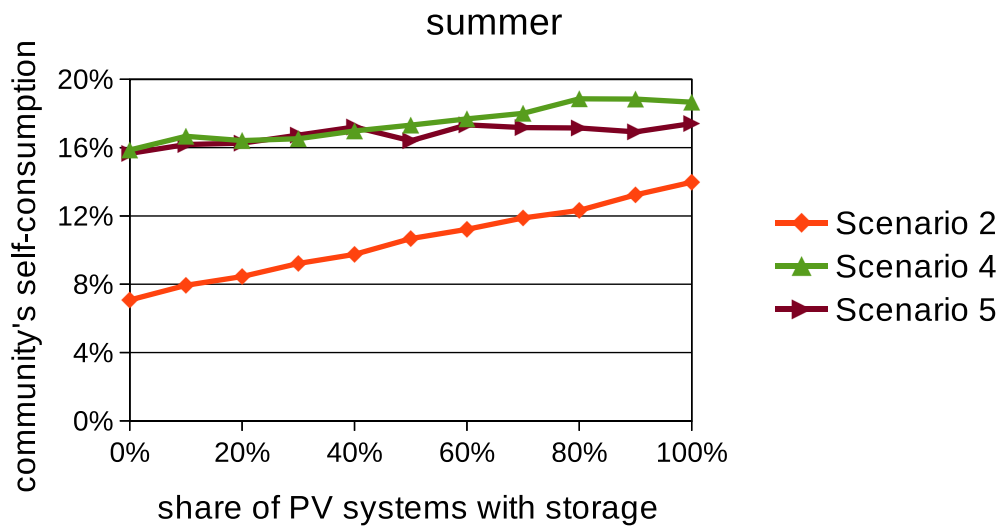

Fig. 4 Simulation results for a summer day modelling the share of photovoltaic systems that also have storage possibilities (batteries)

of the simulation is pointless, the last column presents values related to a battery that is half full ( $50 \%$ of storage capacity).

Although we did not previously include simulation results for changing the number of community members or increasing the capacity of the battery, these results are included in this table. Doubling the size of the community, from 300 to 600 members, does not change the self-consumption values of the default situation. The same holds for the average storage capacity of the batteries.

When considering a doubling of simulated global parameters, a maximum community self-consumption of $28 \%$ has been found. This maximum was reached in scenarios 4 or 5 when $40 \%$ of the households implement a residential PV system (Table 3, third column, last two rows, grey shaded cells). We believe this situation might become a reality in the near future since rapidly increasing numbers of households are installing PV systems, inspired by environmental and/or financial motives. If this trend continues, central energy companies might be faced with a decline in sales of almost $30 \%$. This brings us to the second topic of the paper, the implications of self-consumption for grid management and electricity supply from the grid.

\section{Discussion}

Implications of prosumption for grid management and electricity supply

The rise of prosumption as simulated in the previous section confirms IEA's expectation that prosumption will develop a share of 25 to $30 \%$ in the coming decades. This is already indicated by a simplified simulation model, as we used in the previous section. Under the condition of peerto-peer consumption combined with local storage, a community might develop a prosumption share of about $28 \%$. One of the implications of this is that the management of the medium and low voltage distribution network becomes more important in the overall management of the electricity grid. This trend is visible in the five scenarios explored above.

\section{summer}

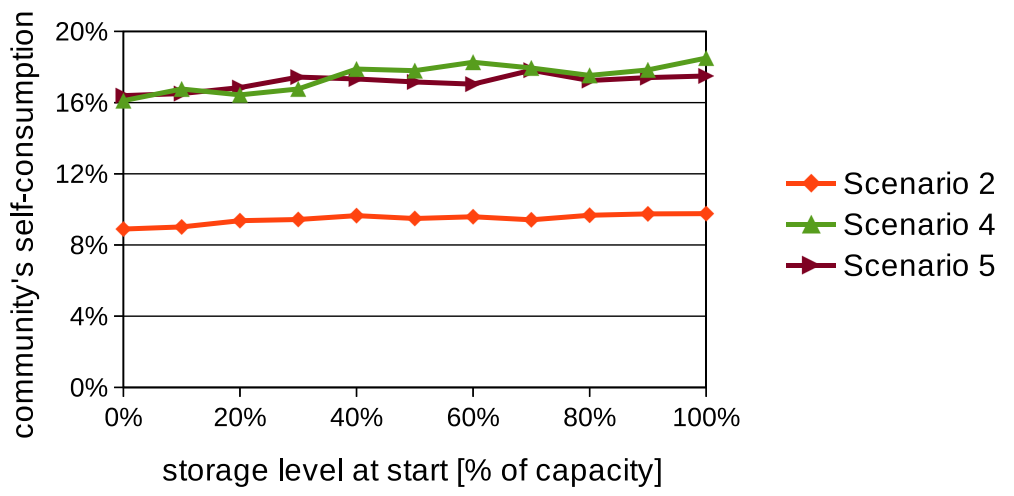

Fig. 5 Simulation results for a summer day modelling the amount of energy stored in the installed batteries at midnight 
Table 3 Numerical results of the simulations showing the community's self-consumption during a summer's day

\begin{tabular}{llllllll}
\hline & Default & $\begin{array}{l}40 \% \text { users with } \\
\text { PV systems }\end{array}$ & $\begin{array}{l}\text { 6-kWp average } \\
\text { PV capacity }\end{array}$ & $\begin{array}{l}600 \text { community } \\
\text { members }\end{array}$ & $\begin{array}{l}50 \% \text { of PV systems } \\
\text { also has storage }\end{array}$ & $\begin{array}{l}\text { 8-kWh average } \\
\text { storage capacity }\end{array}$ & $\begin{array}{l}\text { Half-filled battery } \\
\text { at start of the day }\end{array}$ \\
\hline Scenario 1 & $7.1-7.2 \%$ & $14.5 \%$ & $9.8 \%$ & $7.1 \%$ & & & \\
Scenario 2 & $8.6-8.9 \%$ & $17.7 \%$ & $11.3 \%$ & $8.9 \%$ & $10.7 \%$ & $9.5 \%$ \\
Scenario 3 & $15.5-16.1 \%$ & $25.3 \%$ & $25.1 \%$ & $15.7 \%$ & & $16.7 \%$ & $17.8 \%$ \\
Scenario 4 & $16.1-17.1 \%$ & $28.4 \%$ & $27.0 \%$ & $16.5 \%$ & $17.3 \%$ & $16.2 \%$ & $17.2 \%$ \\
Scenario 5 & $16.1-16.7 \%$ & $27.9 \%$ & $25.8 \%$ & $16.4 \%$ & $16.4 \%$ & & 9 \\
\hline
\end{tabular}

The five prosumption scenarios explored in the previous section have consequences for the prosuming individual household (PV owner), the community, the energy supply company, and the DSO. In all five scenarios, the DSO needs to pay more attention to managing the local (community) grid. The scenarios show that the local focus of the management depends on the prosumption options chosen at the local level. In the first and second scenarios, the local-central interface is a central focus of grid management, due to the production and storage of individual prosuming households. In the other three scenarios, the local grid management itself becomes important due to the involvement of the community. Balancing the local grid, due to peer-to-peer supply combined with individual local storage, becomes the first focal point of the DSO with the central grid as exchange and back-up option. This could mean that prosumption will affect the dominant centralised design and functionality of the grid and the associated cost-ofservice DSO business case. The cost-of-service business case, which is still dominant, charges for the usage and services provided by the grid. This model erodes if the number of prosumers increases, because fewer households use the grid, or else they use the grid only incidentally as back-up. Hence the transportation costs need to be shared by fewer users and this might initiate a death spiral. The more prosumers there are, the fewer grid consumers and the higher the transportation costs for the remaining group of consumers, if the 'cost of service paradigm' in transportation persists. In the Netherlands the transportation costs are socialised, meaning that every consumer in a certain area pays the same tariff for electricity transport and transmission. However, the costs of transport will increase for those who continue to be served by the grid when the number of prosumers increases. If this happens, the central grid might become over-sized, which raises the question for grid companies of how they are going to deal with this challenge in the longer term and how it will affect their longer-term investments in order to avoid disinvestment. In other words, prosumption might lead to what is called the 'utility death spiral', referring to the mechanism that fewer and fewer consumers will face ever-increasing transportation costs, motivating more consumers to become prosumers [1]. Dutch grid operators have recognised this risk and reconsidered their role and function in the future energy system. Currently, they are grid operators and in this role they anticipate prosumption by providing additional services to neighbourhoods, such as storage and demand flexibility. Given the signals from the market, grid operators feel they could play a more active role in facilitating the Dutch energy transition, but here they face legal restrictions with respect to their function and authority.

There are, however, indications that the functionality of the grid might get a new impulse from E-mobility [35]. This report estimates that the increase of E-mobility and electrical vehicles will only be possible with a strong, effective but also smart, centralised grid. The smartness is needed to coordinate the charging of the vehicles. At the same time, the report questions the storage capacity of E-vehicle batteries, because this is financially less attractive than back-up capacity from the grid. Veldman and Verzijlbergh [36] argue for the use of electric vehicles (EV) as a balancing medium for the network with new tariff structures. She uses the example of an EV owner who pays more for rapidly charging his car any time he wants compared to an EV owner leaving the timing and speed of charging to the DSO or supply company. Electric vehicles as well as our modelled parameters: local production, residential storage and peer-to-peer exchange can be part of a so called 'smart grid'.

New developments, leading to a smart grid, require that all parties change their behaviour, including consumers and prosumers. Scholars suggest further research into behavioural change, looking for instance at the context and contingencies that keep electricity consumers in existing routines or getting them out of their routines [37]. Financial incentives from new tariff structures might challenge consumers to change their behaviour. This, though, requires consumers to adapt to differentiated price signals. Prosumers therefore not only need to open up to the communication technology of the smart grid, but also to the incentives of dynamic electricity pricing [38]. This means 
that it is necessary to integrate flexible demand and supply, in particular at the local level. This opens the way for DSOs to develop new products and services, in particular in facilitating an effective balance between local production and local demand. For instance, storage provides opportunities to manage grids more flexibly and efficiently. Area-based storage capacity could be a new future service of a DSO, a service that is currently being explored and tested in pilot schemes in the Netherlands [39].

Apart from developing and offering area-based grid balancing at the local level, the grid manager could also offer expertise to local actors developing a position as prosumer, or develop new modes to organise production and supply in local communities. Research in the Netherlands, initiated by the distribution grid operators, shows that local energy communities challenge the grid company to develop services such as interfaces, web portals, accounts, and administrative procedures, which could facilitate a sustainable local energy supply, rooted in the local community [40]. DSOs can and should play a more dominant role here, in particular also by encouraging and facilitating electricity saving and efficiency improvements. There are several examples of this in the Netherlands, such as the Buurkracht initiative of Enexis, supporting and facilitating neighbourhood energy savings. This service portfolio could also include collective facilities for storing electricity by, for instance, power-to-gas storage and 'the neighbourhood battery'. But, here, the challenge is not only technological but also social. More members of the community should be encouraged to join the community energy system and adjust their energy behaviour to help optimise the community's energy balance. But, changing electricity consumption to match real-time local solar electricity production requires motivation to change consumer behaviour [41]. However, in the Netherlands, only a minority changes its behaviour motivated by ecological considerations [42, 43].

Prosumption opens up the need to reconsider the current consumer segmentation in electricity supply. Prosumption and its development potential require differentiation and flexibility in the grid connections and grid tariffs. DSOs in the Netherlands are now developing financial market models to connect to the changing electricity market to maintain the grid as a reliable and affordable backbone, and to offer flexibility in price and connection to the grid, etc. The development of telecommunication tariffs may serve as an example for electricity supply. In telecommunication the tariff basis developed from hardware to service-based tariffs. Consumers buy capacity rather than paying for a connection to a copper line or a network. Electricity tariffs could develop similarly, by charging for transport capacity instead of grid connection [40]. Capacity tariffs will probably provide a far better match between the load profile and the flexible needs of prosumers. The grid also requires capacity tariffs as an incentive to deal with the poor flexibility of the physical grid. Flexibility in the electricity supply market-for example to deal with extreme weather conditions, sunny days and high winds, which provide extreme peaks in energy supply-requires maximum storage capacity in the grid to accompany the volatility in electricity supply (and demand): an expensive technology for which the customer connected to the grid will have to pay. An intermediate step could be to differentiate and regulate grid usage for peak and non-peak periods on the grid. Prosumption could, for instance, only be allowed to deliver back to the grid outside peak periods. However, here the divergent interests as between the electricity supply company and the DSO might result in suboptimal shifts in electricity demands [44].

Prosumption also affects the business model of the incumbent electricity production/supply company. If the assessment of 25-30 \% of the household consumers moving to prosumption is correct, then the company might face a revenue erosion of the same magnitude if it should fail to find alternative load, for instance in the industrial segment of the market. A second problem the electricity production/supply company is already facing in Europe is the meritorder effect of renewable-based distributed generation, which seriously affects the business model of incumbent providers. Renewables, including the excess production of residential/community $\mathrm{PV}$ panels, are seriously challenging the conventional cost calculation methodology in electricity production, the energy-only market model based on clear price signals. The effect is that incumbents shut down power plants because they are unable to cover the costs of running the plant and earning a return on their investment. The merit-order effect also disturbs investments in new, large-scale production capacity.

All the implications of prosumption sketched out above seriously challenge the regulation of electricity supply. Responding this challenge is no longer a matter of revising current regulatory approaches by improving the price signals in the market [45] or educating the consumer and the prosumer in market participation [38]. Both are needed, but that will probably not be enough to really deal with the challenges of future electricity supply when prosumption has matured. In fact, prosumption challenges the existing conception of electricity. Under a monopoly system, electricity was considered a collective good and regulation was organised accordingly. The public interest was the optimisation criterion under monopoly regulation. In the market, 
electricity is considered a private good with individual profitability and efficiency as the optimisation orientation of regulation. Prosumption adds a new optimisation orientation, which is community interest. This is not all, however. The increasing diversity of energy resources used for electricity generation, as well as the increasing need for storage capacity due to the intermittency of renewables, brings new dilemmas for regulation. This has been clearly shown in recent research $[46,47]$. Nykamp clearly revealed the regulatory dilemmas of storage capacity and investments in distribution grids. In storage, balancing the grid (collective good) is in conflict with the private interest of earning money from storage capacity. The same goes for investments in the distribution grid. The private interest is not to invest in more copper lines to handle peaks, whereas the public interest is investment in smarter energy systems [46]. The regulatory dilemma here is what should be the regulatory orientation for optimisation? Which products and services should be provided by the market and which by the regulated transmission and distribution? Facing these questions only in theory becomes harder and harder in today's highly dynamic electricity market. For that reason the Netherlands offers opportunities to explore and test the challenges under controlled real-life conditions in experimental settings. These examples show that prosumption and its implications present us with a challenging new research agenda since the phenomenon of prosumption itself as well as its implications have been subject to hardly any scientific research. In the science direct database 'self-consumption' appears much more often in the title, keywords or abstract. While until 2012 the number of such articles remains low (less than five a year), the last 3 years show an increase up to 30 . The research agenda on this subject is clearly rising but still rather low.

\section{Model limitations}

The simple model applied in this paper is meant to illustrate possible effects of the combination of increasing application of residential PV systems, inhome storage possibilities and peer-to-peer electricity exchange in a small neighbourhood. We realise the limitations of our simple model. Several developments not yet included in our model can increase or decrease the community's self-consumption. For example, real-life battery characteristics will reduce the overall effect and the introduction of load-flexibility can increase the amount of power produced and consumed within the community without interference from the energy company. This last development is getting more attention in smart grid pilots in the Netherlands. Time of use tariffs for electricity try to persuade households to change the timing of their electricity consumption.

Other physical aspects might influence the actual selfconsumption of a community. The layout of the grid can prevent direct peer-to-peer energy exchange. Currently all houses in a neighbourhood are connected to a distribution station which has a limited capacity. Future alternative layouts are possible.

Although the current paper focusses on electricity, it is important to mention the exchange of different forms of energy as well. At the moment, most houses in the Netherlands use natural gas for heating and fossil fuels for transportation (car). The clear distinction between the different forms of energy used for different purposes is fading. For example electric vehicles are rising and $\mu \mathrm{CHP}$ (combined heat power) systems are being introduced. These developments will influence the self-consumption of electricity, or energy, within a community.

Besides all these, more technical aspects also behavioural aspects should be included. Research points out the importance of household's behaviour on their energy consumption. Several studies try to find factors that influence this consumption. Poznaka et al. [48] analysed how and why the installation of smart metres changed households' electricity use. Frederiks et al. [49] stress the importance of psychology and behavioural economics aspects and Bell et al. [50] point out that households should be studied individually, that their practices result, among others, from social relations. Since agent based modelling is a technique that is used in these disciplines as well, it would be interesting technique in realising interdisciplinary research in this field.

\section{Conclusions}

In this paper we have explored the emerging rise of prosumers in electricity and its implications for grid based electricity supply. With the help of an agentbased model, we have illustrated the evolution of prosumption in a residential community in five scenarios. Depending on the number of prosumers, combined with storage and peer-to-peer supply, we arrived at a share of prosumption in a local community of about $28-30 \%$. This is what can be expected in the short term, provided the emerging trend of prosumption continues as expected by the International Energy Agency. Our analysis of the development of prosumption could only be preliminary, given our rather straightforward model with simple assumptions and changing parameters one at the time per scenario. In reality, the changes will take place simultaneously, amplifying the effects. Moreover, the model 
did not visualise details of a 24-h electricity cycle, which is of course highly relevant in case of prosumption. These and other limitations of the model should be improved in next versions, to facilitate a more detailed and sophisticated analysis. Self-consumption is not yet studied that often with the help of agent-based models. A wide range of interdisciplinary issues related to the rising self-consumption need to be considered. Further research on these issues can enlarge the knowledge on self-consumption within a community. Studies that include aspects from different disciplines are complicated, but we think they are needed in this field.

The second part of the paper discussed some implications of a rising share of prosumption. It showed that the management of the local network will become more important if more households become prosumer in combination with storage and peer-topeer supply. This trend also affects the grid operators' current business models. The energy company is faced with a loss of turnover, which also needs to be compensated by developing alternative business models. We see that both, DSOs and energy companies, are exploring new ways to do business However, they are challenged by the fast pace of new developments and their unfamiliarity with the emerging situation. This paper can increase their awareness of the emerging self-consumption (wishes) of local communities. Developing business models in cooperation with local energy communities could be an attractive alternative to explore, as is currently being explored in the Netherlands. Here also develops an agenda for future research, in particular on the question on the next steps in the development of the electricity grid. Currently the technological side of the development is explored more intensively than the organisational and business side. Our article shows the necessity to focus on the organisational dynamics and its consequences for the business models of incumbents. Elsewhere (Arentsen and Bellekom [21]), we have reflected on the future of the electricity system from an innovation perspective and pointed to an increasing hybridisation in electricity supply, with respect to technology (localised versus centralised), organisation (integrated versus autonomous) and performance (private versus community oriented). Our simple simulation showed a significant bottom-up dynamic by community based presumption with implications for central production and supply. Interesting question here is how this bottom up dynamic will affect the dominant centralised featuring of the electricity system and whether the community is or should be considered as a new and independent agent in the electricity system. Interesting questions for further research on the dynamics in electricity supply.

\section{Appendix: ODD description Overview \\ Purpose}

With this model we want to study the influence of local exchange and/or residential storage on the amount and pattern of demand from and supply to the central grid, of a group of households. We consider the community's self-consumption (or the remaining community's demand from the central grid) as a function of several global parameters. These parameters can be set in the interface of the model.

\section{Entities, state variables and scales}

\section{Entities}

\section{Agents/users}

The model is built with households consuming electricity as agents: the users. Some of these users have installed a residential PV system, these users are called prosumers, the others we name consumers. Some of the prosumers also installed a private storage system. This last group of prosumers has no special name. Figure 6 shows this hierarchy.

\section{Spatial units}

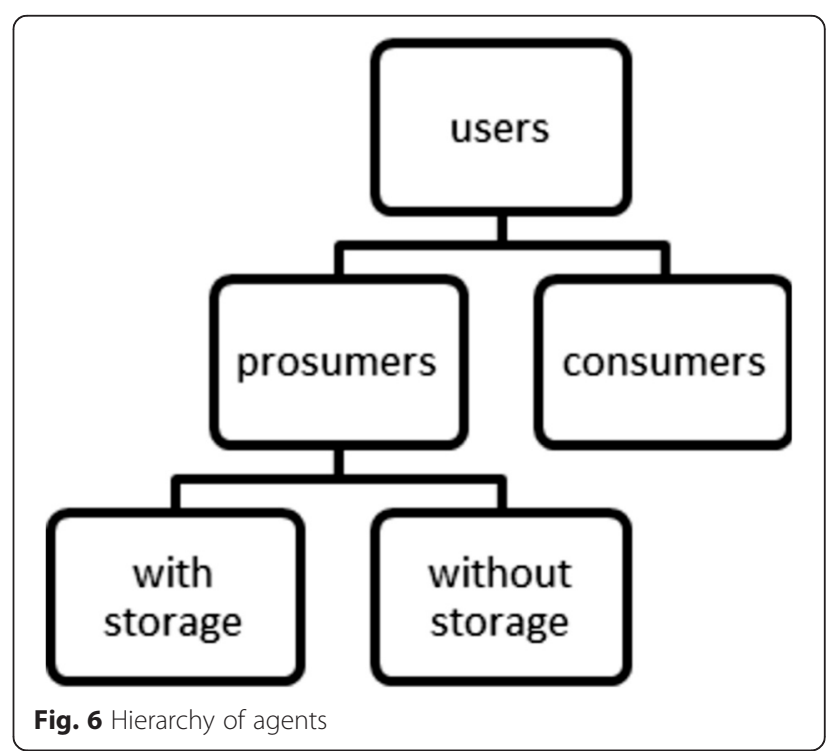

The used agents (users) are represented as patches (grid cells). However, since the model does not (yet) include distance or position, the location is of no significance.

\section{Environment n.a. Collectives n.a.}




\section{State variables}

Users/agents have several variables that determine their (current) situation, Table 4 lists these variables.

Table 4 State variables of the users in the model

\begin{tabular}{|c|c|c|}
\hline Variable & Unit & Dynamics \\
\hline Type of user & Text & $\begin{array}{l}\text { Set Once ("consumer" } \\
\text { or "prosumer") }\end{array}$ \\
\hline Yearly demand & kWh/year & Set once \\
\hline PV capacity & kWp & Set once \\
\hline Storage capacity & kWh & Set once \\
\hline \multicolumn{3}{|l|}{ Patterns } \\
\hline Demand & kWh/time step & Set per time step \\
\hline Production & kWh/time step & Set per time step \\
\hline \multicolumn{3}{|l|}{ Running values } \\
\hline Total consumption & kWh/run & Updated each time step \\
\hline Total grid consumption & kWh/run & Updated each time step \\
\hline Total grid export & kWh/run & Updated each time step \\
\hline Total local consumption & kWh/run & Updated each time step \\
\hline Total local export & kWh/run & Updated each time step \\
\hline Total self-consumption & kWh/run & Updated each time step \\
\hline $\begin{array}{l}\text { Total self-consumption } \\
\text { from PV }\end{array}$ & kWh/run & Updated each time step \\
\hline $\begin{array}{l}\text { Total self-consumption } \\
\text { from storage }\end{array}$ & kWh/run & Updated each time step \\
\hline $\begin{array}{l}\text { Total from PV to } \\
\text { storage }\end{array}$ & kWh/run & Updated each time step \\
\hline Total PV production & kWh/run & Updated each time step \\
\hline Total in storage & kWh/run & Updated each time step \\
\hline \multicolumn{3}{|l|}{ Instantaneous values } \\
\hline Consumption & kWh & $\begin{array}{l}\text { Adapted during electricity } \\
\text { routing (within each time step) }\end{array}$ \\
\hline Grid consumption & kWh & $\begin{array}{l}\text { Adapted during electricity } \\
\text { routing (within each time step) }\end{array}$ \\
\hline Grid export & kWh & $\begin{array}{l}\text { Adapted during electricity } \\
\text { routing (within each time step) }\end{array}$ \\
\hline Local consumption & kWh & $\begin{array}{l}\text { Adapted during electricity } \\
\text { routing (within each time step) }\end{array}$ \\
\hline Local export & kWh & $\begin{array}{l}\text { Adapted during electricity } \\
\text { routing (within each time step) }\end{array}$ \\
\hline Self-consumption & kWh & $\begin{array}{l}\text { Adapted during electricity } \\
\text { routing (within each time step) }\end{array}$ \\
\hline $\begin{array}{l}\text { Self-consumption } \\
\text { from PV }\end{array}$ & kWh & $\begin{array}{l}\text { Adapted during electricity } \\
\text { routing (within each time step) }\end{array}$ \\
\hline $\begin{array}{l}\text { Self-consumption } \\
\text { from storage }\end{array}$ & kWh & $\begin{array}{l}\text { Adapted during electricity } \\
\text { routing (within each time step) }\end{array}$ \\
\hline From PV to storage & kWh & $\begin{array}{l}\text { Adapted during electricity } \\
\text { routing (within each time step) }\end{array}$ \\
\hline PV production & kW & $\begin{array}{l}\text { Adapted during electricity } \\
\text { routing (within each time step) }\end{array}$ \\
\hline In storage & kWh & $\begin{array}{l}\text { Adapted during electricity } \\
\text { routing (within each time step) }\end{array}$ \\
\hline
\end{tabular}

Running values represent aggregate values built up during a run. For example 'total consumption' is increased each time step with the electricity demand of that user/agent in that time step. After each time step running values represent the user's state, like the total amount of electricity consumed by that user since the start of the run. At the end of the run, 'total consumption' thus equals the sum of user's demand values.

Instantaneous values are used during the process of decision making, of distributing electricity. We call this type of state variables 'instantaneous' because they are only temporarily used within the time step and represent the state of a user at a certain instant within that time step.

\section{Scales}

No spatial attributes have been included in the model yet; spatial scale is therefore not relevant in the current version of the model.

Each time step in the model represents $5 \mathrm{~min}$. A run lasts for 288 time steps and represents $24 \mathrm{~h}$, i.e. 1 day.

\section{Process overview and scheduling}

1. Reset instantaneous values of all users

2. Set demand and production values of this time step for all users

3. Routing electricity flows (see section Sub-models (routing electricity flows))

4. Update user's running values and global pattern arrays

\section{Design concepts Basic principles}

The basic principle of the model is to fulfill the power demand of each user at each time step. Electricity obtained from PV panels will be used first to fulfill the owner's demand. When after that they have excess electricity this can be exchanged with other users and/or stored. Stored energy can be used later to fulfill the owner's demand. The central grid handles the remaining demand or excess.

\section{Emergence}

$\mathrm{PV}$, storage and local exchange all influence the amount of self-consumption of the community. This self-consumption on its turn changes the community's consumption of the central grid. The change can occur both in amplitude and in timing. 


\section{Adaptation}

Depending on the global setting, prosumers prefer to store excess electricity or deliver it to their (closest) neighbours.

\section{Objectives}

Each user wants to fulfill its electricity demand in such a way that the demand on the central grid is as low as possible.

\section{Learning}

n.a.

\section{Prediction}

n.a.

\section{Sensing}

Settings like enabling local exchange and/or storage and the preference for either one of them is sensed by all users and used in their way to fulfill their power demand.

\section{Interaction}

Prosumers who wish to deliver excess of electricity to the community deliver the power to their (nearest) neighbours who have not yet fulfilled their demand.

\section{Stochasticity}

The yearly demand of each user is determined by taking a normal distribution with a given average yearly demand of the community and coefficient of variation. The same algorithm is used to set the individual PV capacity and storage capacity.

The coefficient of variation of the yearly demand has a limited value because we assume a certain homogeneity of households within the local community, statistics show only a limited number of differences in Waalre's households. Since PV systems have been applied for quite some years and the capacity (and efficiency) thereof has been steadily growing, we use a relatively large coefficient of variation on this parameter to include older, newer and future systems. Residential storage is a much newer development, so less variation in systems is available. Therefore we assign this parameter a low coefficient of variation of $20 \%$ of the mean value.

To determine the actual demand and production of each user per time step a normal distribution around the mean (from a constant pattern) with a coefficient of variation of $50 \%$ for demand and $20 \%$ for production is applied. These values cannot be changed on the interface. Production from PV panels will be relatively similar since all systems are assumed to be in the same neighbourhood and thus experience the same level of radiation.

Table 5 summarises the applied stochastic values.

Table 5 Parameters which are normally distributed. The coefficient of variation of the first three parameters listed in the table can be set in the interface

\begin{tabular}{ll}
\hline Parameter & Default coefficient of variation \\
\hline Yearly demand & $25 \%$ \\
PV capacity & $50 \%$ \\
Storage capacity & $20 \%$ \\
Demand per time step & $50 \%$ \\
PV production per time step & $20 \%$ \\
\hline
\end{tabular}

\section{Collectives}

n.a.

\section{Observation}

After each run (representing 1 day), the community's total consumption, grid consumption, grid export, local consumption, local export, self-consumption, self-consumption from PV, self-consumption from storage, power from PV to storage and PV production is calculated. The total energy in all storage systems at the end of the run is determined as well. Additionally, some values (consumption, grid consumption and local consumption) are also given for the separate group of prosumers, so excluding the households without PV systems.

Besides the aggregated values of the run also patterns of the intermediate values at each time step are outputted. Time series are produced for the same parameters as the aggregated values and thus represent communitylevel values.

In the current study, each series of runs changes one global (community level) parameter (see section Initialization): average storage capacity, storage level at start, PV systems with storage, average PV capacity, users with PV system or number of users, the other global parameters are set to their default values. Table 6 lists the range of parameter values applied in this study. Each run in a series is repeated 10 times with the same global parameter values to account for statistical variations. Average values on these 10 runs are reported. Larger numbers of repetitions result in slightly smoother graphs but take much longer to finish, the chosen 10 repetitions is a compromise between the two effects. 
Table 6 Studied range of variation of global parameters

\begin{tabular}{llll}
\hline Parameter & $\begin{array}{l}\text { Minimum } \\
\text { value }\end{array}$ & $\begin{array}{l}\text { Maximum } \\
\text { value }\end{array}$ & \\
\hline Number of & 10 & 500 & Much larger numbers have
\end{tabular}

Number of $\quad 10 \quad 500 \quad$ Much larger numbers have users

Users with $\quad 0 \% \quad 100 \%$
PV system

Average PV $\quad 0 \mathrm{kWp} \quad 10 \mathrm{kWp}$ capacity

PV systems $\quad 0 \% \quad 100 \%$ with storage

Average storage $0 \mathrm{kWh}$

$20 \mathrm{kWh}$ capacity

Storage level $\quad 0 \%$

$100 \%$

at start also been modelled but did not show any changing outcomes. In reality not all people in a neighbourhood will join the local exchange community. However, the model cannot (yet) study this situation explicitly since all users in the model are assumed to be willing to participate. Therefore, modelling an increasing share of households joining the exchange community equals modelling an increasing number of users in the system

Percentage of the total number of households in the community (300 for these runs). A value of $100 \%$ corresponds to the situation in which all households have their own PV panels. This is of course a very unlikely situation but we clearly see an increasing number of households with PV systems in recent years.

Currently Dutch households can maximally use $5000 \mathrm{kWh}$ a year in a financial profitable way. This corresponds to about 6.3 kWp [53]. Since we assume this value might increase in future situation we apply a maximum of 10 kWp.

Percentage of the total number of households with PV systems within the community (60 for these runs). The total number of storage systems within the community varies from 0 to 60 with a default of

We assume $20 \mathrm{kWh}$ will be sufficient for a household.

Percentage of the storage capacity and thus varied between 0 (empty, default) and $100 \%$ (full).

\section{Details}

\section{Initialization}

The total number of users, the percentage of users with PV systems and the percentage of PV systems with storage are taken from the interface. Table 7 lists these global model parameters, gives the default value

utilised in this study and includes, where appropriate, a justification of the chosen value. Where possible, we base our default values on data of the municipality Waalre. Individual yearly demand, PV capacity and storage capacity is calculated using the given average and coefficient of variation. The storage level (percentage) is equal for all storage systems.

Table 7 Default initial values of parameters

\begin{tabular}{|c|c|c|}
\hline Parameter & $\begin{array}{l}\text { Default } \\
\text { value }\end{array}$ & Background \\
\hline $\begin{array}{l}\text { Number of } \\
\text { users }\end{array}$ & 300 & $\begin{array}{l}\text { According to Statistics Netherlands } \\
\text { Waalre community had } 2460 \text { households } \\
\text { in } 2012 \text { [54]. For faster computations we } \\
\text { start with a more limited number. }\end{array}$ \\
\hline $\begin{array}{l}\text { Average yearly } \\
\text { demand }\end{array}$ & $\begin{array}{l}4100 \\
k W h\end{array}$ & $\begin{array}{l}\text { Statistics Netherlands gives the number } \\
\text { for Waalre in } 2011 \text { [54]. The Dutch } \\
\text { average for that year equals } 3500 \mathrm{kWh} \text {. }\end{array}$ \\
\hline $\begin{array}{l}\text { Users with } \\
\text { PV system }\end{array}$ & $20 \%$ & $\begin{array}{l}\text { Natuur \& milieu predicts a number of } \\
130.000 \text { PV systems in Dutch households } \\
\text { [55]. Divided by } 7.512 .824 \text { households this } \\
\text { results in } 2 \% \text {. Houses in Waalre are } \\
\text { relatively large and the inhabitants are } \\
\text { wealthier than average. Because of these } \\
\text { characteristics and the expected future } \\
\text { growth in PV we assume a } 20 \% \\
\text { coverage of PV systems. }\end{array}$ \\
\hline $\begin{array}{l}\text { Average PV } \\
\text { capacity }\end{array}$ & $\begin{array}{l}3000 \mathrm{Wp} \\
(=3 \mathrm{kWp})\end{array}$ & $\begin{array}{l}\text { Different values appear in texts ( } 2400 \mathrm{Wp} \\
\text { [56], } 3500 \mathrm{Wp} \text { [57]). We use a slightly } \\
\text { lower value to take into account the } \\
\text { older systems that are still in use. }\end{array}$ \\
\hline $\begin{array}{l}\text { PV systems } \\
\text { with storage }\end{array}$ & $25 \%$ & $\begin{array}{l}\text { We assume only households with PV } \\
\text { systems might decide to install a } \\
\text { residential storage system. Therefore, the } \\
\text { number of storage systems is given as } \\
\text { percentage of households that already } \\
\text { have a PV system installed. Using the } \\
\text { default values for the number of users } \\
\text { and the users with PV systems gives a } \\
\text { default value of } 15 \text { storage systems } \\
\text { within the community. }\end{array}$ \\
\hline \multirow[t]{2}{*}{$\begin{array}{l}\text { Average storage } \\
\text { capacity }\end{array}$} & 4 kWh & $\begin{array}{l}\text { For the US Rastler calculated a desirable } \\
\text { value of } 2 \text { - } 5 \mathrm{~kW} \text { for } 2 \text { to } 4 \mathrm{~h} \text { [58]. } \\
\text { Mulder et al calculated optimum storage } \\
\text { capacity for grid connected houses in } \\
\text { Belgium and they reached values of } 0.3 \\
\text { to } 3 \mathrm{kWh} \mathrm{[16].} \mathrm{In} \mathrm{the} \mathrm{German} \mathrm{situation} 4.5 \\
\text { kWh would provide enough power during } \\
\text { the night [59]. RWE states that } 4 \mathrm{kWh} \text { will } \\
\text { be sufficient for an average } 4 \text { person } \\
\text { household [60]. They offer also much } \\
\text { larger storage systems, ranging from } 4.6 \text { to } \\
41 \mathrm{kWh} \text { [61]. E3/DC sells storage systems } \\
\text { with a usable range of } 4.05 \text { to } 8.1 \mathrm{kWh} \\
\text { net [18]. }\end{array}$ \\
\hline & & $\begin{array}{l}\text { Because of the available systems we model } \\
\text { a default storage capacity of } 4 \mathrm{kWh} \text {. }\end{array}$ \\
\hline $\begin{array}{l}\text { Storage level at } \\
\text { start }\end{array}$ & $0 \%$ & $\begin{array}{l}\text { Start the run (thus the day) with an empty } \\
\text { storage system. }\end{array}$ \\
\hline
\end{tabular}


Patterns of demand and production for a summer or a winter day are read from a file. Global variables are reset to zero.

\section{Input data}

To model the community's electricity interactions, we need data on demand and production for each user. Since both, demand and production, are highly fluctuating, the time resolution of the data should be high.

For the power demand, we use data from the 'Icare' demo [51]. From this demo, it is possible to download electricity demand data with a resolution of about $10 \mathrm{~s}$. Since the time step in the model corresponds to $5 \mathrm{~min}$, we averaged the obtained values to end up with $5-\mathrm{min}$ values.

Several internet sites offer the possibility to share the production data of residential PV systems. From pvoutput [52] it is also possible to download data. We selected a location with a relatively recently installed PV system, in the neighbourhood of Waalre and with high-resolution data. The system consists of nine panels of $250 \mathrm{~W}$ each, heading South East. The power output of the PV system is given per 5 min.

Since the production and, to a lesser extent, the demand depend on the time of the year, we chose 2 days, one in summer and one in the winter season with a daily demand more or less corresponding to the average daily demand of that season. The selected dates are 23 January 2013 and 8 August 2013. Figure 7-10 depicts the patterns we obtained and which are used in the model to determine the demand and production per time step for each user. The patterns are first scaled to the yearly demand and PV capacity of the individual users before the stochastic process to obtain the values per time step (see section Stochasticity) is performed.

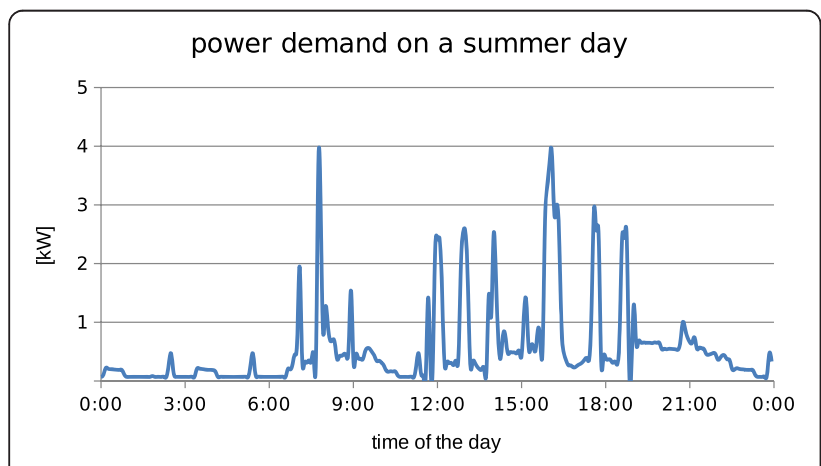

Fig. 7 Power demand on a winter day

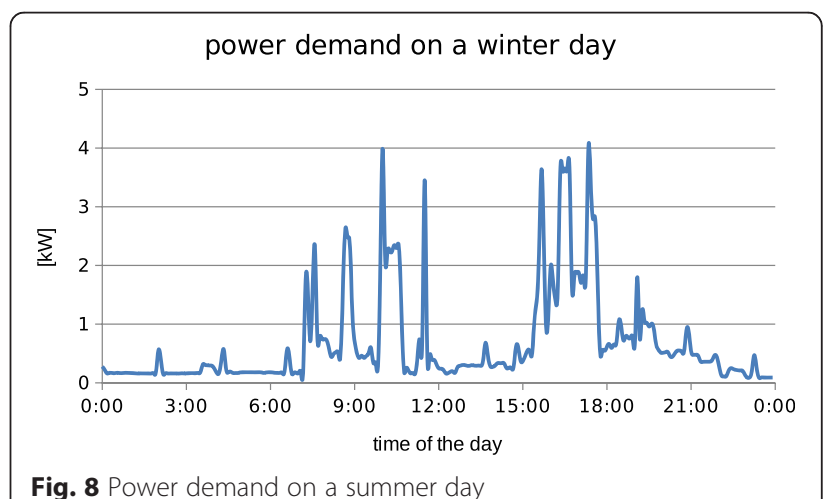

Fig. 8 Power demand on a summer day

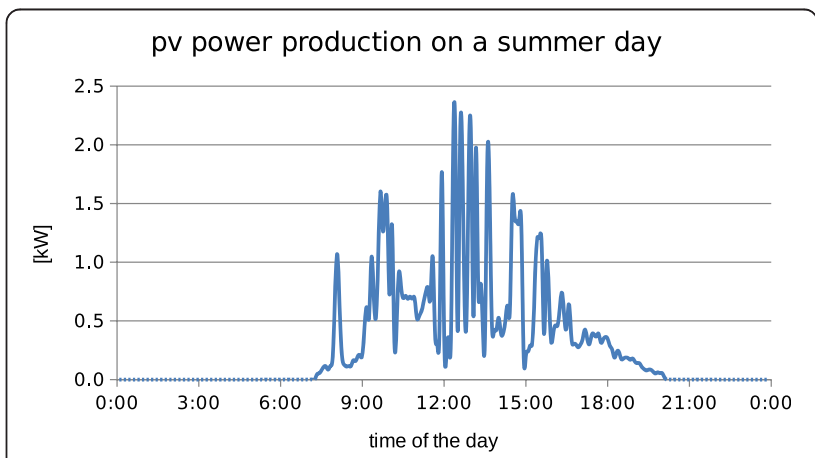

Fig. 9 PV power production on a winter day

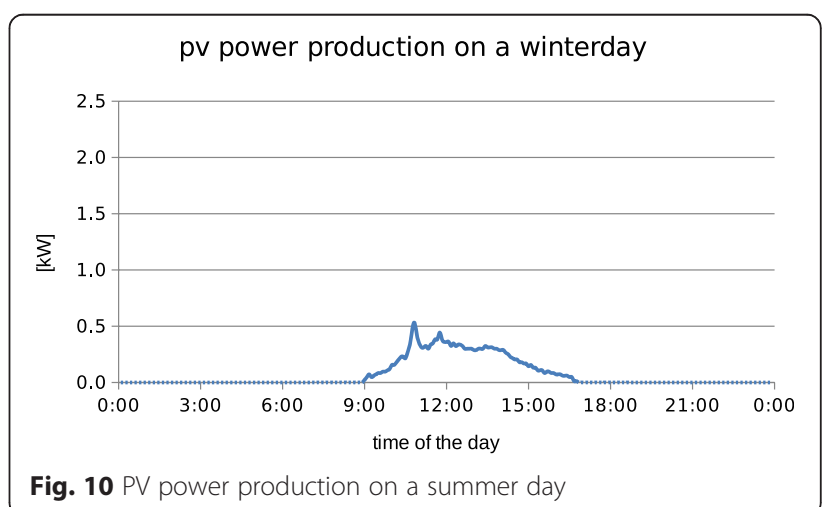

Sub-models (routing electricity flows)

The routing is performed in different stages, following stages are only included when the demand has not been fulfilled in a previous stage and/or the produced electricity had not been delivered. Figure 11 shows the flow diagram of the sub-model in which the electricity flows are routed. 


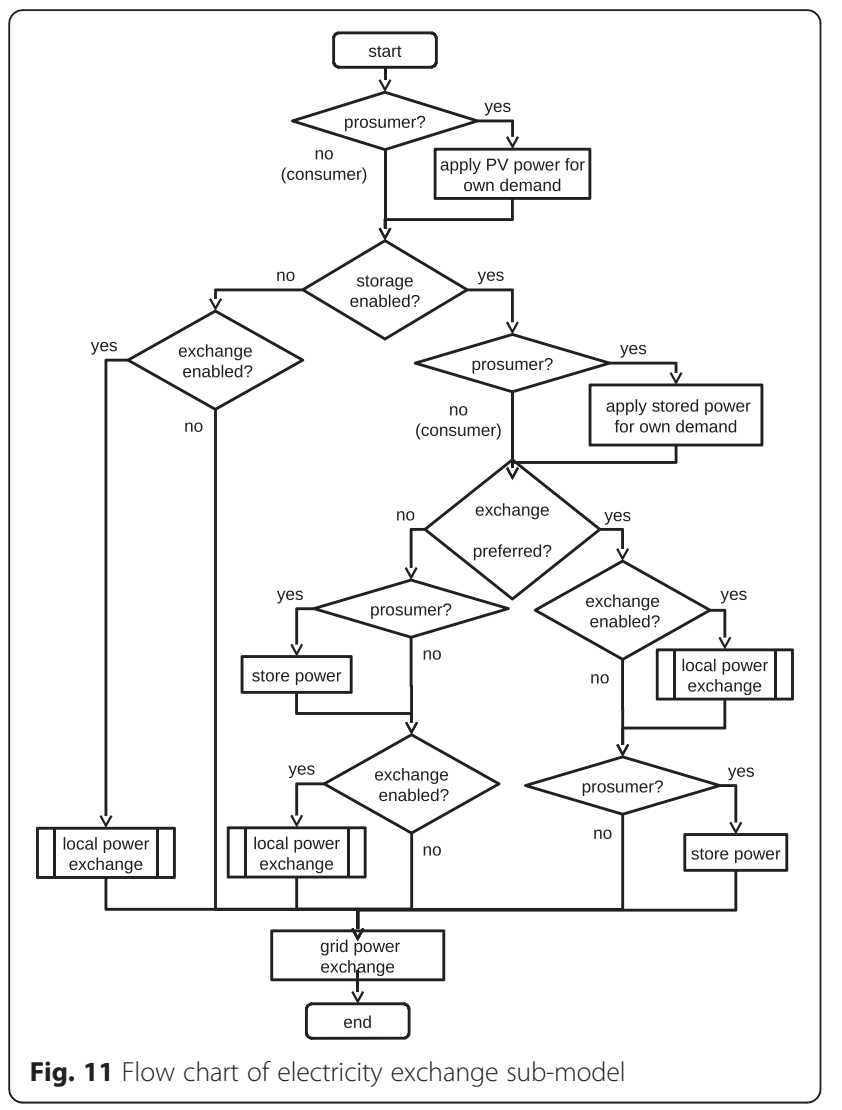

\section{Competing interests}

The authors declare that they have no competing interests.

\section{Authors' contributions}

Within the research SB focusses in the model, MA concentrated on the impact on DSOs and energy companies and KvG added on the new developments within energy companies. The article was jointly prepared by all authors. All authors read and approved the final manuscript.

\section{Authors' information}

Sandra Bellekom worked as a postdoc researcher at CSTM, University of Twente. Afterwards she joined UCD in Dublin where she continued her research on electricity systems but focussed on individual households. Maarten Arentsen is associate professor energy innovation at the University of Twente. His research focuses on change and innovation in electricity supply.

Kirsten van Gorkum works at Enexis and is affiliated with CSTM, University of Twente.

\section{Acknowledgements}

The authors wish to thank the editors and three anonymous referees of this journal for their useful suggestions. Their views have enriched the paper.

\section{Author details}

${ }^{1}$ CSTM University of Twente, Enschede, Netherlands. ${ }^{2}$ Enexis and CSTM University of Twente, Enschede, Netherlands.

Received: 10 February 2016 Accepted: 4 August 2016

\section{Published online: 24 August 2016}

\section{References}

1. IEA-RETD (2014) Residential prosumers - drivers and policy options (Re-prosumers). International Energy Agency, Renewable Energy Technology Deployment, Utrecht, http://statline.cbs.nl/Statweb/publication/
?DM=SLNL\&PA=37823wkk\&D1=11\&D2=2\&D3=0\&D4=8\&D5=2, \&HDR= $\mathrm{G} 3, \mathrm{G} 2, \mathrm{~T} \& \mathrm{STB}=\mathrm{G} 1, \mathrm{G} 4 \& \mathrm{~W}=\mathrm{T}$

2. CBS Statline (2016) Elektriciteit; productie en productiemiddelen. Statistics Netherlands, Den Haag/Heerlen, http://statline.cbs.n//Statweb/publication/ $? \mathrm{WW}=\mathrm{T} \& D M=S L N L \& P A=37823 \mathrm{wkk} \& D 1=11 \& D 2=a \& D 3=0 \& D 4=8 \& D 5=0,2,7,12-$ 16\&HD=160418-1655\&HDR=G3,G2,T\&STB=G1,G4. Accessed 13 Jan 2016

3. Breyer C, Gerlach A (2013) Global overview on grid-parity. Prog Photovolt Res Appl 21(1):121-136

4. Lako P, Beurskens LWM (2012) Policies and opportunities for grid parity of PV in the Netherlands. Energy research Centre of the Netherlands (ECN), Petten, https://www.ecn.nl/docs/library/report/2012/n12002.pdf

5. Lettner G, Auer H (2012) Realistic roadmap to PV grid parity for all target countries. Vienna University of Technology - Energy Economics Group. http://www.pvparity.eu/fileadmin/PVPARITY_docs/documents/PV_PARITY_ D3.3 Roadmap final 2012-10-24.pdf

6. van Sark WGJHM, Muizebelt P, Cace J, de Vries A, de Rijk P (2012) Grid parity reached for consumers in the Netherlands. Paper presented th the 38th IEEE Photovoltaic Specialists Conference (PVSC), Austin. doi:10.1109/PVSC.2012. 6318094, http://ieeexplore.ieee.org.ucd.idm.oclc.org/stamp/stamp. jsp?tp=\&arnumber $=6318094$

7. Mondol JD, Hillenbrand SK (2013) Grid parity analysis of solar photovoltaic systems in Europe. Int J Ambient Energy 35(4):200-2010

8. van Sark WGJHM, Muizebelt P, Cace J, de Vries A, de Rijk P (2014) Price development of photovoltaic modules, inverters, and systems in the Netherlands in 2012. Renew Energy 71:18-22

9. van der Werff E, Steg L (2014) The risk of highlighting financial benefits of pro-environmental actions. Paper presented at the 28th International Congress of Applied Psychology (ICAP), Paris

10. Islam T, Meade N (2014) The impact of attribute preferences on adoption timing: the case of photo-voltaic (PV) solar cells for household electricity generation. Energy Policy 55:521-530

11. Bliek F, van den Noort A, Roossien B, Kamphuis R, de Wit J, van der Velde J, Eijgelaar M (2010) PowerMatching City, a living lab smart grid demonstration. Paper presented at IEEE PES Innovative Smart Grid Technologies Conference Europe (ISGT Europe), Gothenburg. doi:10.1109/ ISGTEUROPE.2010.5638863

12. Zeiss $\mathrm{G}$ (2012) Panasonic announces mass-production of $1.35 \mathrm{kWh}$ battery system for solar-powered homes. http://geospatial.blogs.com/geospatial/ 2012/06/panasonic-announces-mass-production-of-135kwh-battery-systemfor-solar-powered-homes.html. Accessed 6 May 2016.

13. Breen $M$ (2013) The future of energy storage is behind the meter. http://www.greentechmedia.com/articles/read/the-future-of-energy-storageis-behind-the-meter/. Accessed 5 May 2016.

14. Sharma S, Galipeau DW (2012) Optimization of residential grid-tied PV systems without net-metering using load management. Paper presented at the Third IEEE International Conference on Sustainable Energy Technologies (ICSET), Kathmandu, http://ieeexplore.ieee.org.ucd.idm.oclc.org/stamp/stamp. jsp?tp=\&arnumber $=6357367$

15. Castillo-Cagigal M, Caamaño-Martín E, Matallanas E, Masa-Bote D, Gutiérrez A, Monasterio-Huelin F, Jiménez-Leube J (2011) PV self-consumption optimization with storage and Active DSM for the residential sector. Solar Energy 85(9):2338-2348

16. Mulder G, Ridder FD, Six D (2010) Electricity storage for grid-connected household dwellings with PV panels. Solar Energy 84(7):1284-1293

17. E3/DC (2013) E3/DC launches world's first integrated real 3phase DC energy storage system into series. https:/www.e3dc.com/fileadmin/mediacenter/ downloads-fuer-pressevertreter/pressemitteilungenarchiv/PM_2013_01_ E3DC_bringt_weltweit_erstes_integriertes_echt_3_phasiges_DC_ Stromspeichersystem_in_Serie.pdf. Accessed 5 May 2016.

18. E3/DC (2013). S10 - The powerstation (datasheet). http://www.e3dc.com/ files/productflyer.pdf. Accessed 19 Sep 2013.

19. PES (2013) Electric home storage - autonomy for private households and buildings. PES Solar/PV magazine 62-65. http://www.pes.eu.com/assets/ misc_dec/e3dcpdf-217726882333.pdf. Accessed 9 May 2016.

20. Piepenbrink A (2013) Performance and technology review of 400 installed Li-ion home storage systems S10. Paper presented at the 8th International Renewable Energy Storage Conference and Exhibition (IRES), Berlin, http://www.eurosolar.de/ en/index.php?option=com_content\&task=view\&id=582\&ltemid=173

21. Arentsen M, Bellekom S (2014) Power to the people: local energy initiatives as seedbeds of innovation? Energy Sustain Soc 4:2. doi:10.1186/2192-0567-4-2 
22. ERGEG (2009) Position Paper on Smart Grids; An ERGEG Public Consultation Paper; Ref: E09-EQS-30-04. European Regulation Group for Electricity \& Gas, Bruxelles, http://www.energy-regulators.eu/portal/page/portal/EER_HOME/ EER CONSULT/CLOSED\%2OPUBLIC\%20CONSULTATIONS/ELECTRICITY/ Smart\%20Grids/CD/E09-EQS-30-04_SmartGrids_10\%20Dec\%202009_0.pdf. Accessed 6 May 2016

23. Kovacic Z, Giampietro M (2015) Empty promises or promising futures? The case of smart grids. Energy 93:67-74

24. Hu Z, Li C, Cao Y, Fang B, He L, Zhang M (2014) How smart grid contributes to energy sustainability. Energy Procedia 61:858-861

25. Beckman K (2015) Interview Steve Holliday, World Energy Focus, 15 Sep 2015: 3-4. http://worldenergyfocus.org/wp-content/uploads/2015/09/EP_ WEF_2015_15_MR01.pdf. Accessed 2 Nov 2015.

26. van Renssen S (2015). RWE's Head of Innovation Inken Braunschmidt: "We want to be the Uber for energy". Available via Energy Post, 5 October 2015. http://www.energypost.eu/rwes-head-innovation-inken-braunschmidt-wantuber-energy/. Accessed 2 Nov 2015.

27. Gsodam P, Rauter R, Baumgartner RJ (2015) The renewable energy debate: how Austrian electric utilities are changing their business models. Energy Sustain Soc 5:28. doi:10.1186/s13705-015-0056-6

28. Jargstorf J, De Jonghe C, Belmans R (2015) Assessing the reflectivity of residential grid tariffs for a user reaction through photovoltaics and battery storage. Sustain Energy Grid Netw 1:85-98

29. Kästel P, Gilroy-Scott B (2015) Economics of pooling small local electricity prosumers - LCOE \& self-consumption. Renew Sustain Energy Rev 51:718-729

30. Wang $Y$, Lin X, Pedram M (2014) Adaptive control for energy storage systems in households with photovoltaic modules. IEEE Trans Smart Grid 5(2):992-1001

31. Kahrobaee S, Asgarpoor S, Qiao W (2013) Optimum sizing of distributed generation and storage capacity in smart households. IEEE Trans Smart Grid 4(4):1791-1801

32. Wang Z, Gu C, Bale FLP, Sun H (2013) Active demand response using shared energy storage for household energy management. IEEE Trans Smart Grid 4(4):1888-1897

33. CBS (2013) Zonnestroom Hernieuwbare energie in Nederland 2012. Statistics Netherlands, Den Haag/Heerlen, pp 47-51

34. Clover I (2013) Global PV installations to reach 45 GW in 2014, say IHS. PV magazine., Retrieved from http://www.pv-magazine.com/news/details/ beitrag/global-pv-installations-to-reach-45-gw-in-2014-say-ihs_100013773. Accessed 5 May 2016

35. Lemmens J, van der Burgt J, Bosma T, van den Wijngaart R, van Bemmel B, Koelemeijer RPBL (2014) Het potentieel van zonnestroom in de gebouwde omgeving van Nederland. Netherlands Environmental Assessment Agency (PBL), Arnhem, http://www.pbl.nl/sites/default/files/cms/publicaties/pbl2014-dnv-gl-het-potentieel-van-zonnestroom-in-de-gebouwde-omgevingvan-nederland_01400.pdf. Accessed 5 May 2016

36. Veldman E, Verzijlbergh RA (2015) Distribution grid impacts of smart electric vehicle charging from different perspectives. IEEE Trans Smart Grid 6(1):333-342

37. Verplanken B, Wood W (2006) Interventions to break and create consumer habits. J Public Policy Market 25(1):90-103

38. He X, Keyaerts N, Azevedo I, Meeus L, Hancher L, Glachant J-M (2013) How to engage consumers in demand response: a contract perspective. Util Policy 27:108-122

39. Veldman E, Geldtmeijer DAM, Knigge JD, Slootweg JG (2010) Smart grids put into practice: technological and regulatory aspects. Compet Regulat Netw Ind 11(3):287-306

40. Netbeheer Nederland (2011) Net van de toekomst, een verkenning (The future grid: an exploration. In Dutch only). Netbeheer Nederland, Arnhem, http://www.netbeheernederland.nl/Content/Files/373_320008Rapport\%20Net\%20voor\%20de\%20Toekomst.pdf. Accessed 5 May 2016

41. Fiske FST, Taylor SE (1991) Social cognition, 2nd edn. McGraw-Hill, New York

42. CBS (2013) Zonnestroom Hernieuwbare energie in Nederland 2012. Centraal Bureau voor de Statistiek, Den Haag, pp 47-51

43. Kobus CBA, Mugge R R, Schoormans JPL (2015) Long-term influence of the design of energy management systems on lowering household energy consumption. Int J Sustain Eng 8(3):173-185

44. Veldman E, Gibescu M, Slootweg JG, Kling WL (2013) Scenario-based modelling of future residential electricity demands and assessing their impact on distribution grids. Energy Policy 56:233-247
45. Brandstätt C, Brunekreeft G, Friedrichsen N (2011) Locational signals to reduce network investments in smart distribution grids: what works and what not? Util Policy 19(4):244-254

46. Nykamp S (2013) Integrating renewables in distribution grids. Storage, regulation and the interaction of different stakeholders in future grids. Doctorate thesis, University of Twente, Enschede.

47. Buchmann (2015) Information Management in smart grids. Who should govern information management to balance between coordination and competition on the distribution grid level? Paper presented at the 8th CRNI conference, Delft

48. Poznaka L, Laicane I, Blumberga D, Blumberga A, Rosa M (2015) Analysis of electricity user behavior: case study based on results from extended household survey. Energy Procedia 72:79-86

49. Frederiks ER, Stenner K, Hobman EV (2015) Household energy use: applying behavioural economics to understand consumer decision-making and behaviour. Renew Sustain Energy Rev 41:1385-1394

50. Bell S, Judson E, Bulkeley H, Powells G, Capova KA, Lynch D (2015) Sociality and electricity in the United Kingdom: the influence of household dynamics on everyday consumption. Energy Res Soc Sci 9:98-106

51. enerGQ (2013) Uw slimme meter gebruiken om energie te besparen met enerGQ i-CARE. http://www.energq.com/ Accessed 23 Aug 2013.

52. PV output.org (2013) nett-no-energy-consumption $2.250 \mathrm{~kW}$, live output. http://pvoutput.org/intraday.jsp?id=13089\&sid=11537 Accessed 23 Aug 2013.

53. Zonnepaneel op je dak (2015) Salderen: wat is het en hoe zit dat bij mij?http://www.zonnepaneelopjedak.nl/salderen/. Accessed 20 Nov 2015.

54. StatLine CBS (2013) Kerncijfers wijken en buurten 2013. Statistics Netherlands, Den Haag/Heerlen, http://statline.cbs.nl/Statweb/ publication/?DM=SLNL\&PA=70904ned\&D1=16-20\&D2=12942$12948 \& D 3=\mid \& H D R=T \& S T B=G 1, G 2 \& W W=T$. Accessed 5 May 2016

55. Natuur \&en milieu (2013, 6 february 2013). Explosieve groei aantal zonnepanelen op Nederlandse daken (press release 6 Feb 2013). Natuur \& milieu, Utrecht. http://www.biojournaal.nl/artikel/11610/explosieve-groeiaantal-zonnepanelen-op-nederlandse-daken. Accessed 24 Jan 2014.

56. Wilschut M (2012) Zonnepanelen op je dak, hoe doe je dat? Available via Trouw. http://www.trouw.nl/tr/nl/4332/Groen/article/detail/3321867/ 2012/09/25/Zonnepanelen-op-je-dak-hoe-doe-je-dat.dhtml. Accessed 22 Aug 2013.

57. Gerdes J, Seebregts AJ, Luxembourg SL, van der Welle AJ, van Dril AWN, Marbus S, Boelhouwer M (2013) Energietrends 2013. Energy research Centre of the Netherlands (ECN), Petten, https:/www.ecn.nl/publicaties/ECN-E-13-056

58. Rastler D (2010) Electricity energy storage technology options (white paper). Electric Power Research Institute (EPRI), Palo Alto, http://large.stanford.edu/ courses/2012/ph240/doshay1/docs/EPRI.pdf. Accessed 5 May 2016

59. John J S (2013). Is Germany the hot spot for battery-backed solar? http:// www.greentechmedia.com/articles/read/is-germany-the-hot-spot-forbattery-backed-solar. Accessed 29 Nov 2013

60. RWE (2013) Solarstrom speichern: So Groß sollte Ihr Speicher sein. http:// www.energiewelt.de/web/cms/de/1643960/energieberatung/solarenergiephotovoltaik/solarstrom-speichern. Accessed 29 Nov 2013.

61. RWE (2013) HomePower solar Produktbroschüre. http://www.energiewelt. de/web/cms/mediablob/de/1802174/data/1641350/10/energieberatung/ solarenergie-photovoltaik/solarstrom-speichern/rwe-homepower-solar/RWEHomePower-solar-Produktbroschuere.pdf. Accessed 29 Nov 2013.

\section{Submit your manuscript to a SpringerOpen ${ }^{\odot}$ journal and benefit from:}

- Convenient online submission

- Rigorous peer review

- Immediate publication on acceptance

- Open access: articles freely available online

- High visibility within the field

- Retaining the copyright to your article

Submit your next manuscript at springeropen.com 